\title{
ANALISIS MAKNA KONJUNGSI SONOUE DAN SHIKAMO SEBAGAI SINONIM DALAM BAHASA JEPANG
}

\author{
Lina Rosliana \\ Program Studi S1 Bahasa dan Kebudayaan Jepang, Universitas Diponegoro \\ lina.rosliana@live.undip.ac.id
}

\begin{abstract}
(Title: Conjunction Shikamo and Sonoue as a Synonym in Japanese Linguistics) Japanese words have more synonyms than Indonesian words. For example, to say 'increase' in Japanese, we can use fueru (増える), masu (増す), and zouka suru (増加する). Similarly, other words, which in Indonesian equally mean 'bertanya', Japanese has kiku (聞く) and tazuneru (尋ねる). Such synonymous words often make it difficult for the Japanese learner to use them in a sentence, either written or oral, so the analysis of the meaning of synonymous words becomes an important thing in order for conforming the word we choose to the intention we want to convey. This research will discuss conjunctions sonoue (そのうえ) and shikamo (しかも) as synonyms, both of which can be paired with 'selain itu' in Indonesian. This study will be described with explanation pf every meaning that both conjunctions have, as well as similarities and differences in terms of meaning and usage. The method used is an analytic descriptive method. The object of this research is Japanese sentences that use sonoue and shikamo conjunctions, and a case study of both conjunctions.
\end{abstract}

Keywords :conjunction, sonoue, shikamo, synonym

\section{PENDAHULUAN}

Konjungsi dalam kelas kata bahasa Jepang termasuk kedalam kelompok kelas kata yang dapat berdiri sendiri dan tidak memiliki perubahan. Konjungsi dapat menghubungkan kata, frasa, klausa, maupun kalimat. Konjungsi dalam bahasa Jepang dibagi menjadi 10 kelompok sebagai berikut.
1. Konjungsi yang menunjukkan alasan atau penyebab, misalnya: dakara, sorede, sonotame, sokode 'karena itu'

2.Konjungsi yang menunjukkan penambahan alasan, misalnya: nazenara, 'penyebabnya adalah'

3. Konjungsi yang menunjukkan asal mula, misalnya: sorenara, suruto 'jika begitu'

4. Konjungsi yang menunjukkan kebalikan, misalnya: shikashi, daga, dakedo 'tetapi' 
5. Konjungsi kesetaraan, misalnya: soshite, mata, oyobi 'lalu', soreni, sorekara, shikamo, sonoue 'selain itu'

6. Konjungsi yang menunjukkan pertentangan, misalnya: ippou, gyakuni, hantaini 'sebaliknya'

7. Konjungsi yang menunjukkan pemilihan, misalnya: matawa, aruiwa 'atau'

8. Konjungsi yang menunjukkan penambahan penjelasan, misalnya: tsumari, sunawachi 'yaitu'

9. Konjungsi yang menunjukkan pengubahan tema, misalnya: tokorode, soredewa 'ngomong-ngomong'

10. Konjungsi yang menunjukkan ringkasan, misalnya: ijou, kokomade 'demikianlah'

Konjungsi dalam bahasa Jepang seperti yang telah dicontohkan di atas sangat beragam namun beberapa konjungsi memiliki kemiripan makna, sehingga menyulitkan para pembelajar bahasa Jepang dalam menggunakannya. Penelitian ini akan membahas tentang konjungsi yang menunjukkan kesetaraan, yaitu sonoue dan shikamo. Kedua konjungsi ini memiliki kemiripan makna dan sama-sama dapat dipadankan dengan '(tidak hanya)...juga...' 'dan lagi' atau 'juga' dalam bahasa Indonesia. Berikut adalah contoh kalimat yang menggunakan konjungsi sonoue dan shikamo.
(1) ごちそうになり、そのうえお土産までいただ いた。

Gochisouni nari, sonoue omiyage made itadaita.

Tidak hanya dijamu, (saya) juga diberi oleh-oleh.

(2) 彼はそれをやった、しかもりっぱに。

Kare wa sore wo yatta, shikamo rippani.

Dia tidak hanya melakukannya, dia juga melakukannya dengan baik.

\section{KAJIAN TEORI}

Teramura (1982), sebelumnya pernah meneliti tentang persamaan dan perbedaan konjungsi mo, shi, dan shikamo. Dalam penelitiannya, Teramura menyebutkan bahwa konjungsi shikamo yang muncul pada sebuah klausa atau kalimat, sebenarnya memiliki fungsi yang mirip dengan konjungsi mo, dan shi. Hanya saja, shikamo lebih mengandung subjektivitas atau penilaian pribadi dari si pembicara, sedangkan mo dan shi lebih netral (1984:73). Dalam penelitian ini, Teramura tidak membahas keterkaitan dengan konjungsi sonoue.

Iori dalam bukunya, Nihongo Bunpou Handbook (2004), menyebutkan, terdapat konjungsi yang memiliki kemiripan arti seperti sarani, sonoue, 
shikamo, omakeni. Di antara keempat konjungsi tersebut, sonoue dan shikamo lebih banyak digunakan saat mengungkapkan pernyataan yang subjektif.

Izuhara Eiko (2007), pernah melakukan penelitian tentang konjungsi sonoue dan shikamo yang dimuat dalam jurnal Aichi Gakuin University. Ia mengaitkan kedua konjungsi ini dengan konjungsi lain dengan makna yang hampir sama, yaitu soreni, soshite dan sorekara.

Kata-kata yang memiliki kemiripan makna dikenal sebagai sinonim. Namun, dalam kemiripan makna tersebut kita masih dapat menemukan perbedaannya, karena menurut Palmer (1981:89) tidaklah mungkin kata-kata memiliki makna yang sama persis dapat terus hidup bersamasama dalam sebuah bahasa. Palmer menyatakan setidaknya ada 5 cara untuk mengidentifikasi perbedaan kata-kata yang bersinonim, yaitu:

1. Sinonim yang dipengaruhi oleh dialek daerah tertentu dalam sebuah bahasa. Misalnya, dalam bahasa Inggris terdapat kata fall dan autumn untuk menunjukkan musim gugur. Fall dipakai di Amerika, sementara autumn lebih banyak dipakai di Inggris.
2. Sinonim yang dipengaruhi oleh situasi pemakaiannya. Misalnya, dalam bahasa Indonesia terdapat kata mati, meninggal dan gugur. Meninggal dan gugue dianggap lebih sopan jika dibandingkan mati.

3. Sinonim yang dipengaruhi oleh makna emotif, sementara secara kognitif dianggap tidak memiliki perbedaan. Misalnya, kata liberty dan freedom. Dalam bidang politik, seseorang akan memilih kata yang dianggap lebih memberikan dampak emosional tertentu kepada lawan bicaranya.

4. Sinonim yang dipengaruhi pasangan kolokasinya. Misalnya, kata nasi dapat berkolokasi dengan menanak atau memasak. Sinonim jenis ini masih diperdebatkan karena kesamaan yang dimiliki oleh kata-katanya hanya datang dari medan makna yang sama.

5. Sinonim yang dipengaruhi oleh kedekatan makna semata. Sinonim jenis ini banyak dieksploitasi oleh pembuat kamus. Misalnya, dalam bahasa Inggris kata mature bersinonim dengan adult; ripe; due.

Sementara itu, masih menurut Palmer, relasi makna dari kata-kata yang dianggap bersinonim dapat dianalisis dari antonim yang dimilikinya. Misalnya, kata superficial 'dangkal' dalam bahasa Inggris memiliki antonim deep dan profound 
'dalam'. Di sisi lain, kata shallow 'dangkal' memiliki antonim deep juga. Hal ini dapat dijadikan dasar untuk menyimpulkan bahwa superficial dan shallow adalah sinonim karena sama-sama memiliki antonim deep.

\section{METODE}

Untuk memahami konjungsi sonoue dan shikamo dalam bahasa Jepang, penelitian ini akan menganalisis makna kedua konjungsi tersebut dan mencari persamaan perbedaan dari keduanya. Kajian kebahasaan yang dilakukan dalam penelitian ini digunakan telaah sinkronis, yaitu bahasa Jepang modern yang digunakan pada masa sekarang ini. Sementara generalisasinya dilakukan secara induktif, yaitu berdasarkan pada hasil analisis kedua konjungsi tersebut yang berpedoman pada data dari berbagai sumber (jitsurei). Sumber data diambil dari kalimat-kalimat dalam website berbahasa Jepang, kamus-kamus, dan karya-karya ilmiah lainnya yang dipublikasikan maupun yang tidak.

Penelitian ini merupakan penelitian yang berada dalam ranah semantik leksikal. Menurut Pateda (2010), semantik leksikal merupakan cabang dari semantik yang menyelidiki makna unsur-unsur kosakata suatu bahasa secara umum sebagai satuan mandiri tanpa memandang posisinya dalam kalimat. Menurut Pateda pula, sebuah kamus merupakan contoh yang tepat untuk semantik leksikal karena makna tiap kata diuraikan dalam kamus. Penelitian ini pun mencoba menyelidiki makna dari konjungsi sonoue dan shikamo tanpa memperhatikan struktur keduanya dalam sebuah kalimat. Penelitian ini menitik beratkan pada makna konjungsi sonoue dan shikamo sebagai satuan mandiri.

\section{HASIL DAN PEMBAHASAN}

Dalam Kamus Bahasa JepangIndonesia karangan Kenji Matsuura (1998), sonoue dan shikamo masing-masing diberi arti:

Sonoue: lagipula; tambahan pula (lagi); dan lagi.

Shikamo: lagi; pula

Sementara itu, Iori (2004:474), menyebutkan bahwa konjungsi sarani, sonoeu, shikamo, dan omakeni memiliki kemiripan makna dengan konjungsi soshite, yaitu semuanya menekankan pada makna dakedenaku $\sim$ mo (bukan hanya....juga....). Namun, penggunaan soshite dalam kalimat tidak dapat digantikan oleh sonoue atau shikamo.

Berikut adalah contoh-contoh kalimat yang dii dalamnya terdapat konjungsi 
soshite, yang kemudian disubtitusi dengan konjungsi sonoue dan shikamo.

(1) デパートへ行った。そして靴を買った。

Depaato e itta. Soshite kutsu wo katta.

(Saya) pergi ke departemen store.

Kemudian (saya) membeli sepatu.

(1’) デパートへ行った。笛のうえ靴を買

った。( $(x)$

Depaato e itta. Sonoue kutsu wo katta.

(Saya) pergi ke departemen store. Dan lagi, (saya) membeli sepatu.

(1’’) デパートへ行った。しかも靴を買っ

た。 $(x)$

Depaato e itta. Soshite kutsu wo katta.

(Saya) pergi ke departemen store. Dan lagi, (saya) membeli sepatu.

Izuhara (2007), menguraikan bahwa persamaan dari sonoue dan shikamo adalah, keduanya sama-sama dipakai saat ingin memberi tambahan sifat atau keterangan pada topik sebuah kalimat. Misalnya:

（2）美味しい！簡単！そのうえ健康！

Oishii! Kantan! Sonoue kenkou!

Lezat! Mudah! Dan lagi, menyehatkan!

（3）体によくて、簡単で、しかもおしゃれな料 理!
Karada ni yokute, kantan de, osharena ryouri!

Masakan yang baik untuk tubuh, simpel, menarik lagi!

Pada kalimat (2), topik kalimatnya dilesapkan, namun jika kita amati baikbaik, kita dapat memperkirakan bahwa topiknya adalah seputar masakan, topik yang sama dengan kalimat (3). Terlepas dari apa topik yang sebenarnya dari kalimat (2) di atas, konjungsi sonoue dan shikamo memiliki fungsi yang sama, yaitu menambahkan keterangan pada topik.

Seperti yang telah dijelaskan sebelumnya, dalam buku Nihongo Bunpou Handbook dijelaskan, sonoue dan shikamo sama-sama mengandung rasa subjektivitas si pembicara. Namun, shikamo lebih menekankan perasaan si pembicara, yang biasanya menunjukkan perasaan terkejut, senang, atau susah. Jika kita amati kembali kalimat (2) dan (3) di atas, kalimat (2) menjelaskan bahwa topik kalimat (masakan) tersebut lezat（美味しい)， mudah membuatnya (簡単), dan lagi (その うえ) menyehatkan (健康). Sonoue dalam kalimat (2) dipakai saat ingin menambahkan keterangan, bahwa masakan tersebut juga menyehatkan. 
Kemudian kalimat (3) menjelaskan bahwa masakan tersebut jika dimakan baik untuk tubuh（体にいい）, mudah membuatnya (簡単), menarik lagi! (しかも おしゃれな料理). Dalam kalimat (3), si pembicara menceritakan bahwa masakan tidak hanya baik untuk tubuh dan mudah membuatnya saja, tapi di luar dugaan, masakan tersebut pun menarik (penampilannya). Karena itulah, sonoue cenderung dipakai untuk memberikan penilaian yang netral terhadap sesuatu, sedangkan shikamo tidak. Hal ini tampak pula dari contoh-contoh kalimat berikut:

(4) あの人は名門大学の出身でハンサムで す。そのうえ、性格もいいです。

Ano hito ha meimon daigaku no shusshin de hansamu desu. Sonoue, seikaku mo ii desu.

Orang itu tampan dan berasal dari universitas kenamaan. Dan lagi, sikapnya pun baik.

（5）彼は英語が話せるんです。そのうえ、フラ ンス語も話せるんです。

Kare wa eigo ga hanaserundesu.

Shikamo furansugo mo hanaserundesu.

Dia dapat berbicara bahasa Inggris.

Dan lagi, bahasa Perancis pun dia bisa.

（6）彼は試験に受かった。しかもトップだった。
Kare wa shiken ni ukatta. Shikamo toppu datta.

Dia lulus ujian tersebut. Dan lagi, (dia) peringkat teratas.

（7）彼にいろいろ教えてもらった。しかも、学 費まで払ってもらって感動した。

Kare ni iroiro oshiete moratta. Sonoue, gakuhi made haratte moratte kandou shita.

(Saya) diajarkan banyak hal oleh dia. Dan lagi, uang kuliah (saya) pun dibiayai, (saya) sungguh terharu.

Pada kalimat (4) dan (5), konjungsi sonoue memperlihatkan perasaan si pembicara, namun dalam penilaian yang masih netral. Sonoue menunjukkan penambahan keterangan untuk topik pembicaraan, yaitu ano hito 'orang itu' pada kalimat (4) dan kare 'dia' pada kalimat (5).

Sementara itu, pada kalimat (6) dan (7) konjungsi shikamo menunjukkan penambahan keterangan untuk topik pembicaraan dan memperlihatkan subjektivitas pembicara terhadap topik pembicaraan tersebut. Pada kalimat (6), pembicara menunjukkan kekagumannya terhadap kare 'dia' yang berhasil lulus ujian dan meraih peringkat teratas. Jika konjungsi shikamo disubstitusi oleh sonoue, 
kalimat tersebut masih berterima secara makna, namun nuansa yang dikandungnya bergeser dari kalimat subjektif menjadi kalimat netral. Dalam hal ini pembicara hanya ingin menambahkan informasi saja terkait kare 'dia' yang berhasil lulus ujian juga meraih peringkat teratas.

Begitu pula pada kalimat (7), dengan menggunakan konjungsi shikamo, pembicara ingin menunjukkan perasaan senangnya secara subjektif atas apa yang telah ia terima dari seseorang. Jika konjungsi shikamo pada kalimat (7) disubstitusi oleh sonoue, meskipun masih berterima secara makna, penggunaannya menjadi kurang tepat, karena perasaan senang dan terima kasih dari si pembicara tidak dapat tersampaikan.

Dalam dictionary.goo.ne.jp, perbedaan sonoue dan shikamo dijelaskan sebagai berikut:

「その上」も「かも」も、二つの状態、

状況を重ねて述べる点では同じ用法であり、 判断や心理を伴う場合に用いられる。

Sonoue dan shikamo dapat digunakan dalam situasi dan kondisi yang sama, namun perbedaannya dapat dilihat dari pandangan dan emosi pembicara.

Secara praktis, konjungsi sonoue dan shikamo dapat digunakan secara bergantian sebagai bentuk variasi. Orang Jepang memandang jika penggunaan sebuah kata yang sama diucapkan terus-menerus bukanlah hal yang bagus. Karena itulah konjungsi yang maknanya berdekatan seringkali digunakan secara bergantian seperti dalam kalimat berikut:

（8）彼女は美人。しかも頭がいい。气の うえ性格までもいいのですから、結婚出来 ないわけがありません。

Kanojo wa utsukushii. Shikamo atama ga ii. Sonoue seikaku mademo ii nodesukara, kekkon dekinai wake ga arimasen.

Dia wanita yang sangat cantik. Dia juga pintar. Selain itu, sifatnya pun baik, jadi tidak mungkin kalau dia tidak bisa menikah.

\section{Dengan demikian, sonoue dan} shikamomerupakan dua buah konjungsi yang bersinonim. Keduanya memiliki kedekatan makna yang dalam banyak situasi dapat saling bersubstitusi.

Perbedaan dari konjungsi tersebut dapat dilihat dari sisi emotif atau penilaian yang dimiliki oleh pembicara/penulis kepada lawan bicaranya/pembaca.

\section{SIMPULAN}

Konjungsi sonoue dan shikamo, dalam bahasa Indonesia dapat dipadankan 
dengan 'selain itu' atau 'dan lagi', yang dipakai saat ingin menambahkan keterangan dari sebuah topik kalimat. Sonoue dan shikamo, jika disubstitusikan pada kalimat yang sama, makna kalimat tersebut tidak berubah. Sehingga bisa dikatakan bahwa konjungsi sonoue dan shikamo adalah dua kata yang bersinonim.

Namun, tetap saja dua kata yang berbeda, meskipun bersinonim, memiliki perbedaan. Sonoue dan shikamo samasama mengandung rasa subjektivitas si pembicara. Namun, shikamo lebih menekankan perasaan si pembicara, yang biasanya menunjukkan perasaan terkejut, senang, atau susah. Dengan kata lain, konjungsi sonoue dan shikamo termasuk ke dalam sinonim yang dipengaruhi oleh makna emotif, sementara secara kognitif dianggap tidak memiliki perbedaan. Sinonim yang dipengaruhi oleh nilai emotif pada umumnya dipakai untuk memberikan dampak emosional tertentu kepada lawan bicara.

\section{DAFTAR PUSTAKA}

Iori, Isao. dkk. 2002. Nihongo Bunpou Handbook. Tokyo: Three A Network.

Jurnal. Izuhara, Eiko. 2007. Tenka Setsuzokushi Shikamo, Sonoue no Saikou. Aichi Gakuin University.

Matsuura, Kenji. 1998. Kamus Bahasa Jepang - Indonesia. Kyoto: Kyoto sangyou University Press.

Palmer, F.R. 1981. Semantics. Cambridge: Cambridge University Press.

Pateda, Mansoer. 2010. Semantik Leksikal. Jakarta: Rineka Cipta

Sutedi, Dedi. 2003. Dasar-dasar Linguistik Bahasa Jepang. Bandung: Humaniora.

Teramura, Hideo. 1982. Nihongo no Shintakkusu to Imi I. Tokyo: Kuroshio Shuppan. 